\title{
REVIEWS.
}

\section{PRACTICAL METHODS IN BIOCHEMISTRY.}

By Frederick C. Koch. 2nd Edition. Ballière, Tindall and Cox. London. 1937. Price 10/-.

There is already a sufficiency of good books on practical biochemistry, so that in order to justify its existence any new work must have some special excellence and this we feel is the case with " Practical Methods in Biochemistry."

The chapters on carbohydrates, lipins and proteins are very good and contain short theoretical accounts explanatory of the various characteristic tests described. The account of hydrogen ion concentration is less happy; partly because the theoretical consideration is too short; this should be either amplified or omitted. Further, the actual method of the concentration chain merits detailed description. In the case of gastric digestion the use of the two indicator method for estimating free and combined acidity is not clearly explained, although the intelligent student would probably discover the necessary details in the chapter on hydrogen ion concentration. There are excellent chapters on blood analysis and a full account of Van Slyke's methods. Most of the methods described are satisfactory, but we have not found the estimation of potassium according to Breh and Gaebler to be accurate. These are only minor points however, and this book should prove of real value to students of biochemistry and to biochemical specialists seeking a short and accessible work of reference. It should also be useful to medical students taking their second examination, although the territory covered is a good deal more extensive than they are likely to traverse.

\section{A MANUAL OF TUBERCULOSIS.}

By E. AshwORTH UNDERWOOD, M.A., B.Sc., M.D., D.P.H. Second Edition. Livingstone. Price $8 / 6 \mathrm{~d}$.

It is a pleasure to welcome this new edition of Dr. Underwood's book, which has now been considerably enlarged to appeal more directly to a widening circle of readers. Originally written as a guide for nurses engaged in tuberculosis work, this book now contains much valuable information and is an equally helpful guide for all those indispensable units in this work, almoners, hospital administrators, members of local authorities and tuberculosis care committees. For the modern nurse tuberculosis in all its aspects is adequately dealt with; the main principles are well brought out, and the nurse's duties and responsibilities in the management of the various classes of patient are described fully. Modern treatments, artificial pneumothorax and the various surgical procedures for pulmonary tuberculosis, gold therapy, heliotherapy, the recent changes in the treatment of surgical tuberculosis, are all given due prominence; and in other ways, as on the epidemiological and administrative aspects, the book is fully up to date, though it is perhaps a pity that there is no mention of P.P.D. in dealing with the tuberculins. The writing is clear, and there is a useful summary at the end of each chapter. The reviewer knows of no book in our language which so adequately covers the same field and for the same class of readers, as this one; and it is confidently anticipated that this edition will enjoy an even greater success than the earlier one, for it is a book that can be recommended to all who are interested in and have to deal with tuberculosis problems.

\section{PRE-NATAL AND POST- NATAL MANAGEMENT.}

By J. St. George Wilson, M.C., F.R.C.S., F.C.O.G., Obstetric and Gynæcological Surgeon, Royal Infirmary Liverpool. Pp. 206. London: Edward Arnold \& Co., 1937. Price $10 / 6$ net.

Mr. St. George Wilson in this manual has produced a concise record of the essentials of his subject without including the wider conceptions of pre-natal and post-natal management. It is a work completely without "padding" and is characterized throughout by a dogmatism which is laudable. The 
author at times becomes almost provocative when he states his belief that physical exercises as a preparation for labour are useless and that Hegar's sign is elicited with the vaginal fingers in the posterior fornix.

The outstanding section of the book is an admirable discussion on trial labour in which the author stresses the importance of uterine inertia rather than malposition and disproportion as a cause of delayed labour.

The diagrams throughout show a high standard of excellence and Mr. Wilson has made good use of these to illustrate his often brief text. Liberal use has also been made of radiographs which prove to be equally informative. The work is beautifully produced and will prove to be of immense value to those interested in the ante-natal and post-natal care of patients. It is essentially practical and the author in his inimitable style has chosen to be so dogmatic in his statements that he is convincing.

\section{POISON.}

\section{The history, constitution, uses and abuses of poisonous substances.}

By Hugo Glaser. Translated into English by MARGUERITE WOLFF. Hutchinson's Scientific and Technical Publications. 1937. Price $8 / 6$ net.

There are so many substances which are harmless or even beneficial when given in small doses, but which act destructively when taken in excess, that a book on poison is bound to cover a wide range. Indeed, were a Mithridates to re-appear he would require a vast edition to his armamentarium in order to have any chance of safety.

Mr. Hugo Glaser endeavours to tell us something of the uses and abuses to which poisonous substances have been put, together with notes on their history and constitution. Needless to say, the crime interest is strong and many notable cases are recorded. The book is readable, but suffers from its size, in so much that in a volume of under 300 pages it is manifestly impossible to do more than give a very brief account of the poisons mentioned, and the information gleaned is therefore unlikely to be sufficient either to the student of toxicology or to a prospective poisoner.

On page 30 , under Gas Warfare, the $\stackrel{\leftrightarrow}{\Rightarrow}$ author states that "at the beginning of the of War the Germans never contemplated the use of poison gas, and there is good reason to believe both that they first utilized it some months later than the Allies and that it was a long time before they made up for the delay." This is not in accord with the British Official History of the War.

The chapter on Alcohol is disappointing and covers less space than that devoted to Cocaine.

Apart from minor compositor's errors, notably one on p. 162 in which Liebig's discovery of Chloroform is dated 1931-the book is well printed and the translation into English by Marguerite Wolff reads well, but we question whether this book reaches the standard expected from its inclusion in a series of "Scientific and Technical Publications."

\section{TREATMENT OF SOME CHRONIC AND "INCURABLE" DISEASES.}

By A. T. Todd, O.B.E., M.B.(Edin.) M.R.C.P.(Lond.), Honorary Physician, $\overrightarrow{\vec{P}}$ Bristol Royal Infirmary. Bristol: John Wright \& Sons Ltd. London: Simpkin Marshall Ltd. 1937. Price 10/- net.

Medicine as a whole accepts or rejects its facts on much the same basis as any other science, but by reason of the fact that it deals with human beings and that humanity demands that it shall relieve symptoms even when unable to discover their basic cause, there is a side of its practice which is known as "the art" of medicine. The importance of this aspect of medical work is enhanced because man is controlled in his everyday $\tilde{N}$ life, and his behaviour is conditioned, by his circumstance.

This should not be taken to mean that medical science is any less exacting in its demands for accuracy, or that such facts as are accepted and acted upon are less $\stackrel{\infty}{\rightarrow}$ subject to scrutiny than those which obtain 0 in less humane sciences. The time has passed when mere statement or even reitera- 